\title{
ИСПОЛЬЗОВАНИЕ ГЕОФИЗИЧЕСКИХ МЕТОДОВ ДЛЯ ИЗУЧЕНИЯ КРИОГЕННОГО СОСТОЯНИЯ ПОРОД РАЗРАБАТЫВАЕМЫХ ЗОЛОТОРУДНЫХ МЕСТОРОЖДЕНИЙ МАГАДАНСКОЙ ОБЛАСТИ
}

\author{
Хасанов И. М., ${ }^{1,3}$ Волков В. Н. ${ }^{2}$ \\ ${ }^{\prime}$ ФБГУН Северо-Восточный комплексный научно-исследовательский институт им. Н. А. Шило \\ ДВО РАН, г. Магадан \\ ${ }^{2}$ Южный федеральный университет, г. Ростов-на-Дону \\ ${ }^{3}$ Северо-Восточный государственный университет, г. Магадан \\ Email: aumaglan@yandex.ru; vnvvnv1952@gmail.com
}

\begin{abstract}
Рассматривается проблема приложения и информативности методов наземной геофизики для изучения состояния массивов пород в криолитозоне. На примере золоторудных месторождений Магаданской области изучены и проанализированы особенности изменения значений удельного электрического сопротивления и вызванной поляризации грунтов в зависимости от их криогенного состояния. Обосновывается достаточновысокаяэффективность геофизических методов при разграничении талых, сезонно-талых, локально мерзлых и многолетнемерзлых пород. Результаты исследований рекомендуется использовать для оптимизации процессов разработки месторождений в различных инженерно-геологических условиях.
\end{abstract}

Ключевые слова: многолетнемерзлые породы, таликовые зоны, геофизические методы, электротомография, удельное электрическое сопротивление, вызванная поляризация.

DOI: $10.34078 / 1814-0998-2021-1-30-39$

\section{ВВЕДЕНИЕ}

Гидрогеологические условия криолитозоны характеризуются значительной изменчивостью. Для получения информации о геокриологическом состоянии горных пород требуется бурение значительного количества скважин с отбором образцов и проведением каротажных исследований. Но даже после выполнении большого объема трудозатратных и дорогостоящих работ не всегда удается получить исчерпывающую информацию о гидрогеологических условиях месторождений. Применение методов наземной геофизики позволяет обеспечить достаточную информативность и экономичность при решении указанных проблем.

Геофизические методы в комплексе с гидрогеологическими достаточно эффективны при оконтуривании разноранговых таликовых зон, изучении их морфологии в плане и разрезе, выделении областей многолетнемерзлых пород, поиске участков повышенной трещиноватости в коренных породах (и, как следствие, их обводненности) (Зыков, 2007; Якупов, 2008; Мельников и др., 2010; Хасанов и др., 2011а,б). Включение геофизических методов в состав гидрогеологических исследований позволяет зна-

(С Хасанов И. М., Волков В. Н., 2021 чительно снизить объем бурения и стоимость работ.

В работе излагаются результаты изучения криогенного состояния массива горных пород россыпного месторождения золота, расположенного в среднем течении р. Дебин и коренного золоторудного месторождения Кубака, находящегося в верховьях р. Омолон: Центрально-Колымского и Омолонского регионов Магаданской области (рис. 1, 4).

\section{МАТЕРИАЛ И МЕТОДЫ ИССЛЕДОВАНИЯ}

Исследования криогенного состояния верхней части разреза (ВЧР) многолетнемерзлых пород (0-20 м) базировались на авторских материалах, полученных в процессе выполнения полевых геологоразведочных работ в 2015-2018 гг. (ООО «ЗДК»), и опубликованных данных.

Для решения поставленных задач был применен комплекс геофизических исследований, который включал в себя: электропрофилирование (СЭП-ВП) и электрозондирование методами ВЭЗ-ВП (аппаратура МЭРИ-24, ИМВП, АСТРА$100)$, ЗСБ (Цикл-7) и георадарное профилирование (Лоза-Н1).

Интерпретацию материалов электрозондирований проводили с помощью программ RES2DINV, IPI2win2, «Подбор» и «Крот». 


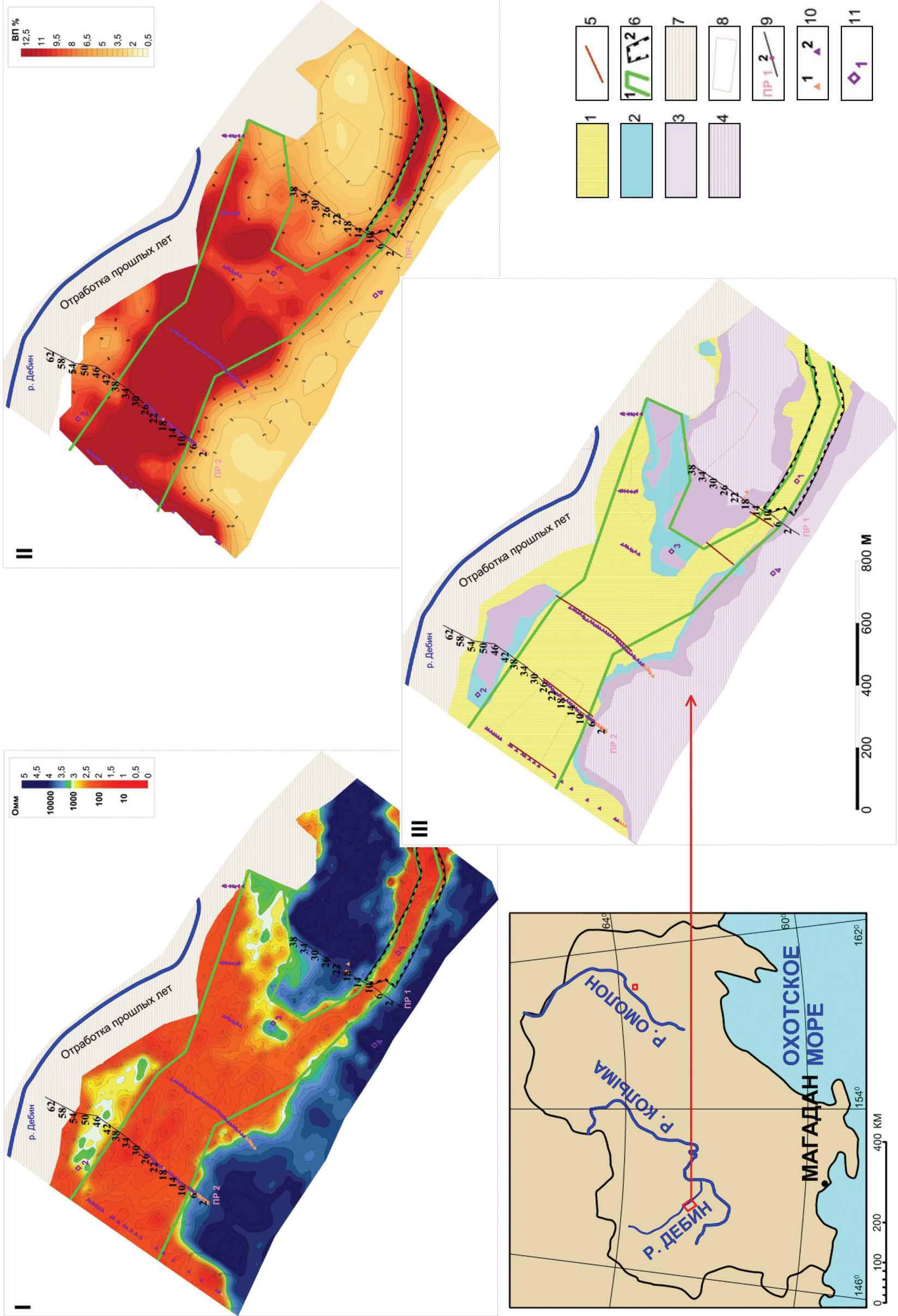


Puc. 1. Обзорная схема территории исследований. Планы изолиний УЭС (I), ВП (II) и схема интерпретации (III): 1 - талики и таликовые зоны в диапазоне глубин 1-20 м; 2 - сезонно-талые породы; 3 - породы очаговой мерзлоты; 4 - многолетнемерзлые породы; 5 - заверочные канавы; 6 - предлагаемый по геолого-геофизическим данным (1) и отработанный дражный полигон (2); 7 - отработка прошлых лет; 8 - полигоны с концентрацией золота более 0.5 г/ м³; 9 - профили ВЭЗ-ВП (электротомография), их номера и пикеты; 10 - точки измерения температурного режима положительные (1), отрицательные (2); 11 - точки наблюдений симметричных ВЭЗ-ВП (Шлюмберже), их номера. УЭС - удельное электрическое сопротивление; ВП - вызванная поляризация; ВЭЗ вертикальное электрическое зондирование

Fig. 1. Overview of the research area. Schemes for SER (I), IP (II) isolines and the interpretation scheme (III): 1 - taliks and talik zones in the depth range of $1-20 \mathrm{~m} ; 2$ - seasonally thawed rocks; 3 - rocks of patchy permafrost; 4 - permafrost; 5 - confirmatory trenches; 6 - site proposed by geologic-geophysical data (1) and measured dredging site (2); 7 - past years' development; 8 - sites with concentrations of gold exceeding $0.5 \mathrm{~g} / \mathrm{m}^{3} ; 9$ - VES-IP (electrotomography) profiles, their numbers and pickets; 10 - temperature measurement points - positive (1) negative (2); 11 - observation points for symmetric VES-IP (Schlumberger), their numbers. Abbreviations: SER - specific electric resistivity; IP - induced polarization; VES - vertical electrical sounding

\section{РЕЗУЛЬТАТЫ РАБОТ И ИХ ОБСУЖДЕНИЕ}

Россыпь Дебин. В геологическом строении района принимают участие терригенные отложения юры, представленные преимущественно углисто-глинистыми сланцами, реже алевролитами, песчаниками и туффитами. Рыхлые аллювиальные отложения залегают в долине р. Дебин и подразделяются по возрасту на позднечетвертичные и современные. Литологический состав аллювия поймы и высокой пойменной террасы представлен так (сверху вниз): растительный слой, ил, торф (0.0-0.4 м); ил и глина с галькой и валунами различного состава и размера (до 0.4-2.0 м); галька различных размеров осадочных пород, слабосцементированная песком и глиной, мелкие валуны гранитов (до 10-20\%), линзы льда, гравий (2.014.0 м); галька различных размеров, сцементированная глиной, щебень разрушенных песчаноглинистых сланцев (14.0-15.0 м). Мощность аллювиальных отложений составляет 8.0-15.0 м. В целом для этих образований характерна достаточно высокая льдистость.

Гидрогеологические условия района характеризуются наличием грунтовых безнапорных вод: надмерзлотных и межмерзлотных. Воды маломощного сезонно-талого слоя распространены повсеместно и циркулируют в аллювиальных, отложениях и трещиноватых коренных породах. Воды надмерзлотных и межмерзлотных (сквозных) таликовых зон приурочены к руслам рек. Водоупорным горизонтом является толща многолетнемерзлых пород (ММП).

По гидрогеологическим условиям на исследуемом участке физическое состояние рыхлых отложений в основной своей массе многолетнемерзлое. В стержне русловой части водотока р. Дебин установлено наличие надмерзлотных и сквозных таликовых зон. По степени минерализации воды пресные - 30-100 мг/дм³. По составу они преимущественно гидрокарбонатные кальциевые и сульфатные натриевые, кислые и слабощелочные ( $\mathrm{pH}$ изменяется от 4.2 до 7.8).

Сравнительный анализ выполненных геофизических исследований позволил установить геоэлектрические элементы криогенного строения геологической среды в плане и разрезе в диапазоне глубин 1-20 м. Основные объекты поиска таликовые зоны, регистрируются удельным электрическим сопротивлением (УЭС) менее 500 Ом и значениями параметра вызванной поляризации (ВП) от 9 до $12 \%$.

Сезонно-талые породы, имеющие распространение в приповерхностном слое до 3-4 м, составляющие сезонно-талый слой (СТС), обладают сопротивлением 500-1000 Ом и вызванной поляризацией 7-9\%.

Локально мерзлые породы, или очаговая (островная) мерзлота, представляют собой чередование в разрезе талых и мерзлых пород. Как правило, это приповерхностные талые породы в пределах деятельного слоя. Сложный характер взаимодействия незамерзшей воды с минеральным скелетом и льдом обусловливает широкий диапазон, изменения УЭС от 3 до 10 тыс. Ом и ВП 5-8\% мерзлых грунтов.

Многолетнемерзлые породы имеют существенно более высокие значения УЭС, свыше 10 тыс. Ом, и низкие ВП, менее 5\% (см. рис. 1-3).

Результаты электрического зондирования методом электротомографии представлены в виде геоэлектрических разрезов (рис. 2). На них отражено распространение в различной степени мерзлых и талых пород в разрезе. Данные симметричного четырехэлектродного электрического зондирования фиксируют наиболее характерные криогидрогеологические условия состояния горных пород от талых и сезонномерзлых до очаговых и многолетнемерзлых (рис. 3).

Приведенные электрические характеристики горных пород, полученные разными установками, сопоставимы между собой, что указывает на 
ПРОФИЛЬ 1

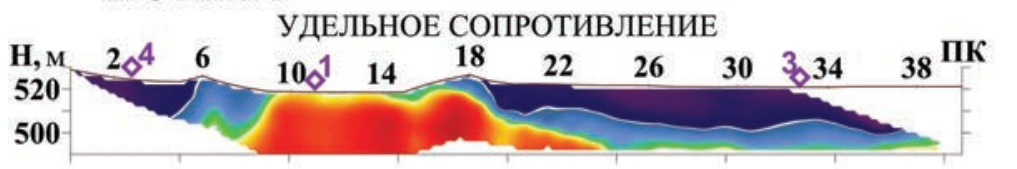

ВЫЗВАННАЯ ПОЛЯРИЗАЦИЯ

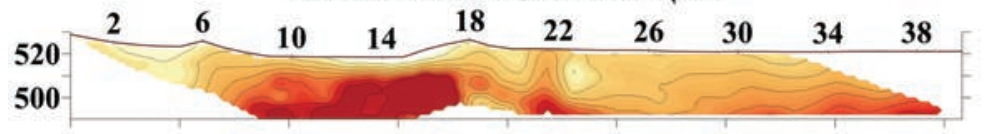

ГИДРОГЕОЛОГИЧЕСКИЙ РАЗРЕЗ

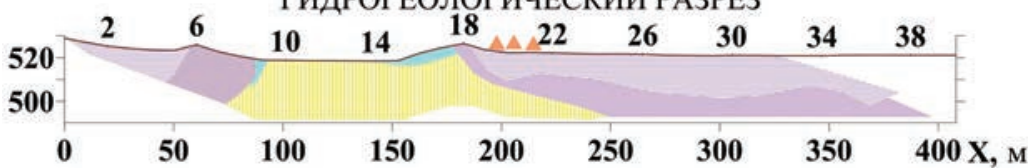

Шкалы интенсивности

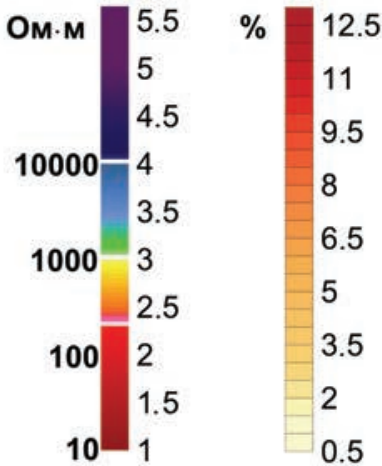

ПРОФИЛЬ 2

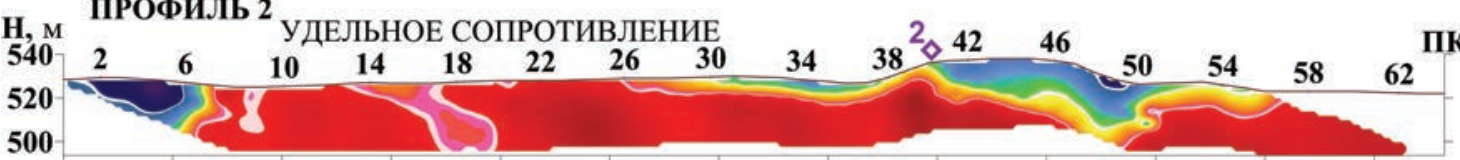

500
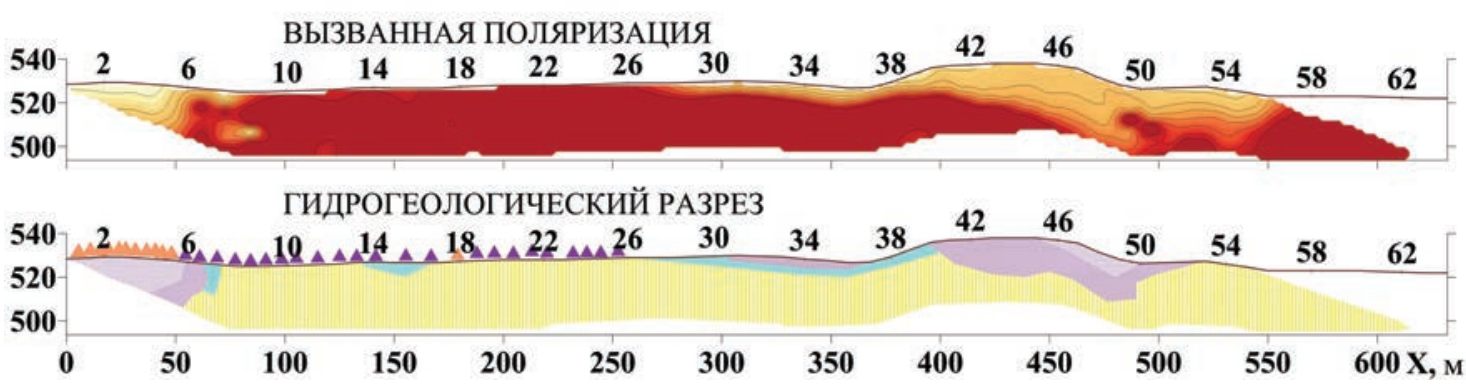

Puc. 2. Геоэлектрические разрезы ВЭЗ-ВП (электротомография) и их интерпретация. Условные обозначения см. на рис. 1

Fig. 2. Geoelectric sections of VES-IP (electrical tomography) and their interpretation. For symbols, see Fig. 1

достоверность выделяемых градаций криогенного состояния верхней части разреза.

Тесная корреляция между геокриологическими параметрами пород с их УЭС и ВП позволяет установить основные черты строения геологической среды по латерали и до глубин, определяемых линейными размерами измерительных линий (разносов).

В результате работ выделены надмерзлотные, сквозные и подмерзлотные таликовые зоны и по ним намечены полигоны для дражной отработки (см. рис. 1). В границах полигона отработки пройдено несколько заверочных канав глубиной от 3 до 6 м, которые подтвердили результаты геофизических исследований об отсутствии мерзлых пород. По полотну канав и по всей площади были проведены измерения температуры грунтов в естественном залегании. Их результаты также согласуются с геофизической диагностикой наличия талых и мерзлых пород (см. рис. 1, 2).

Резкое увеличение УЭС обводненных грунтов в зоне отрицательных температур закономерно связано с образованием льда в порах и трещинах, который обладает высоким (более 10 тыс. Ом·м) удельным сопротивлением (Зыков, 2007;
Якупов, 2008; Мельников и др., 2010; Хасанов и др., 2011а,б; Нерадовский, 2013).

Увеличение ВП талых пород по сравнению с мерзлыми связано с рядом механизмов, обусловливающих естественные электрохимические процессы. Первый - содержание глинистого материала. Породы, содержащие тонкодисперсное глинистое вещество, имеют заметную поляризацию и могут обладать повышенной вызванной поляризацией, соизмеримой с той, которая характерна для рудной вкрапленности (Оленченко, 2002). Второй связан с существованием функциональной связи между проницаемостью и поляризацией. В данном случае подразумевается движение жидкости в порах породы под воздействием наложенного поля. Это существует в зоне аэрации, где влага находится в порах и капилляpax в подвешенном состоянии, в виде гигроскопической, стыковой и пленочной воды. Наличие водопроницаемых таликовых зон, по которым осуществляется перенос свободной гравитационной воды, существенно увеличивает значения вызванной поляризации.

Резкое снижение значений поляризуемости (в 2 раза и более) отмечается при промерзании грунтов, содержащих средние и крупные пес- 


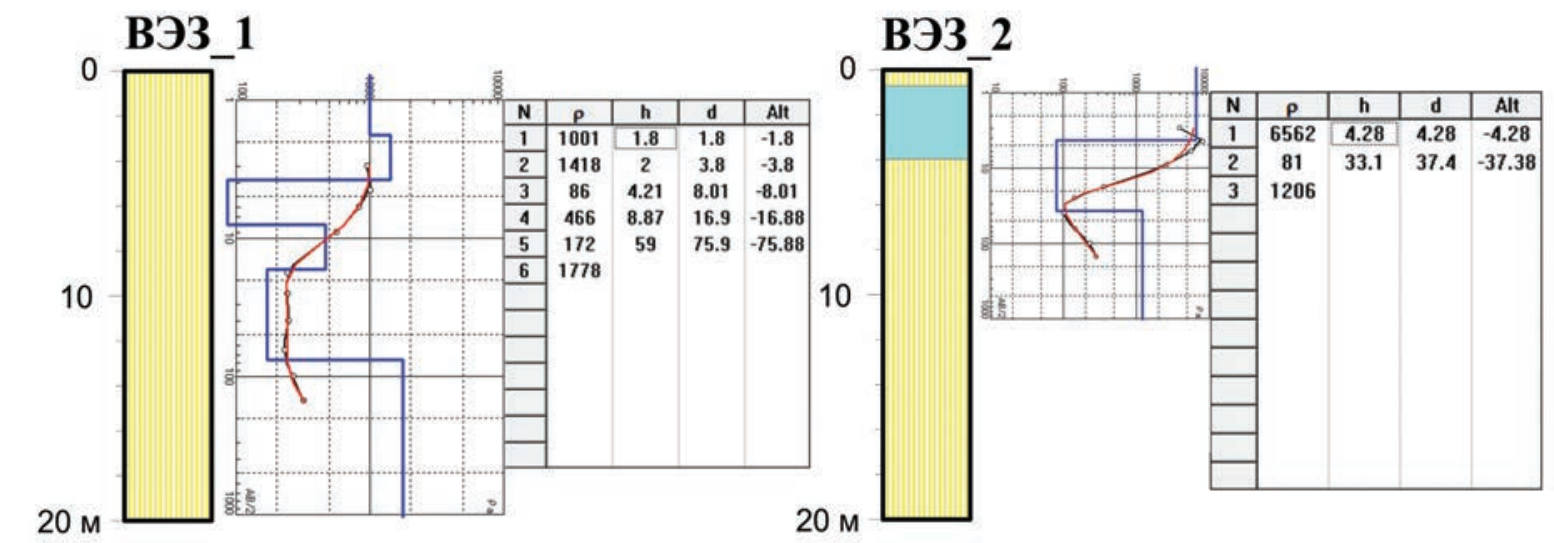

ВЭ3 3

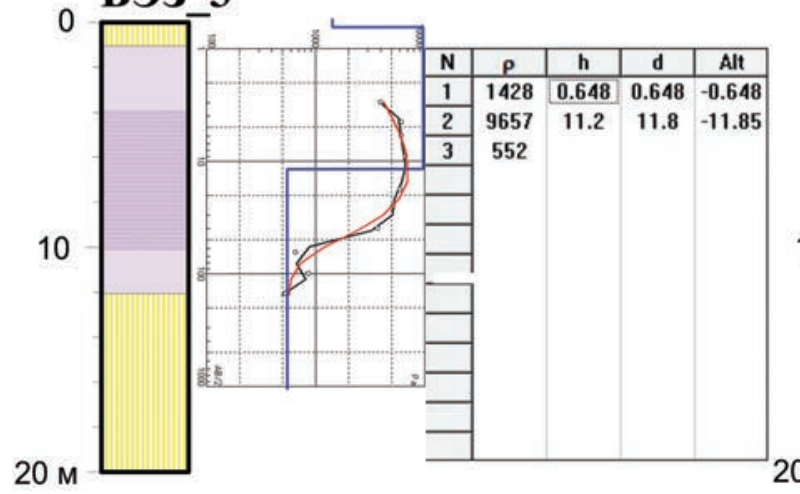

ВЭ3 4

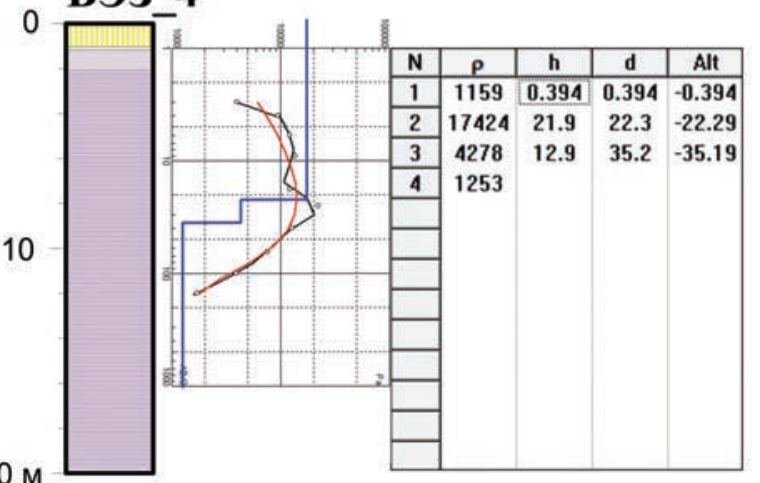

Puc. 3. Результаты симметричного ВЭЗ-ВП (установка Шлюмберже). Условные обозначения см. на рис. 1

Fig. 3. Results of symmetrical VES-IP (Schlumberger array). For symbols, see Fig. 1

чаные фракции (0.315-1.25 мм), что, вероятно, определяется процессами, протекающими во всех трех типах воды (свободной, рыхло- и прочносвязанной), одновременно существующих в соизмеримых количествах при данной температуре (Кормильцев, 1980).

Таким образом, в результате геофизических исследований установлены закономерности в изменении значений УЭС и ВП, обусловленные различным криогидрогеологическим состоянием горных пород: талых, сезонно-талых, локально мерзлых, многолетнемерзлых. На основе полученных геофизических материалов выделены таликовые зоны, пригодные для прохода драги и отработки промышленных блоков, а также участки распространения многолетнемерзлых пород, которые без искусственного растепления отработать невозможно.

Золоторудное месторождение Кубака, Цокольная рудная зона. Территория месторождения сложена преимущественно покровными и субвулканическими фациями умеренно кислых и средних по составу вулканитов (игнимбриты, риолиты, трахидациты, туфы), переслаивающихся с вулканогенно-осадочными образованиями (туфопесчаники, туфоалевролиты) среднего девона - нижнего карбона. Чехол четвертичных образований представлен аллювиальными, водно-ледниковыми отложениями: валунами, галечниками, песками, илами.

Исследуемая часть месторождения залегает в толще ММП, расположенных в долине р. Кубака, характеризующихся мощностью не более 25100 м и температурой $-1.5 \ldots-5.5^{\circ} \mathrm{C}$.

Подземные воды Цокольной рудной зоны распространены в толще рыхлых четвертичных отложений, а также в зонах экзогенной и тектонической трещиноватости коренных пород.

В соответствии с принятой на Северо-Востоке России стратификацией, в пределах изученной части Цокольной рудной зоны выделены следующие гидрогеологические подразделения (А. М. Пак, В. П. Карчавец, 2005 г.):

1. Водоупорный криогенный комплекс четвертичных отложений различного генезиса. Общая мощность слагающих комплекс отложений не превышает 20 м, составляя в среднем 5-10 м. Промороженные отложения комплекса представлены галечно-гравийными отложениями с песчаным и супесчано-суглинистым заполнителем, щебенисто-древесными с супесчано-суглинистым заполнителем, валунно- 
галечниковым материалом с песчано-суглинистым заполнителем;

2. Водоупорный криогенный массив раннекаменноугольно-средне-позднедевонских пород. Массив представлен мерзлыми игнимбритами и туфами трахидацитов, туфопесчаниками, туфоалевролитами. Мощность их изменяется от 50 до 90-160 м;

3. Сезонно-водоносный горизонт четвертичных отложений. Мощность в зависимости от состава водовмещающих отложений, экспозиций склона и характера растительности изменяется от 0.2 до 1.5 м. Питание водоносного горизонта осуществляется за счет инфильтрации атмосферных осадков и воды, образующейся при оттаивании льдистых образований. Разгрузка происходит в поверхностные водотоки. Как источник обводнения горных выработок сезонноводоносный горизонт четвертичных отложений опасности при горно-подготовительных и эксплутационных работах не представляет, что подтверждается многолетней отработкой открытым и подземным способами Центральной зоны месторождения;

4. Водоносный таликовый горизонт современных аллювиальных отложений $\left(\mathrm{aQ}_{\mathrm{IV}}\right)$. Раз- вит локально в пределах таликовых зон в днище долины р. Кубака. Водовмещающие отложения представлены галечником с валунами и песчано-гравийным заполнителем. В нижней части разреза в составе заполнителя присутствуют пылеватые и глинистые частицы. Мощность отложений 8.5-9.0 м. Гидрогеологические объекты аллювиальных отложений имеют гидравлическую связь с поверхностными водами и подземными водами нижележащих коренных пород;

5. Водоносная таликовая зона трещиноватости раннекаменноугольно-средне-позднедевонских вулканогенных и вулканогенноосадочных пород $\left(\mathrm{C}_{1}-\mathrm{D}_{2-3}\right)$ приурочена к сквозным таликам. Она является вторым от поверхности водоносным объектом и отделена от аллювиального водоносного горизонта маломощным (12 м) прерывистым слоем элювиальных образований. Эта зона характеризуется трещинным и трещинно-жильным типами проницаемости. Тип и величина проницаемости определяется преимущественно степенью трещиноватости, что позволяет объединить разновозрастные стратиграфические образования в единое гидрогеологическое подразделение.
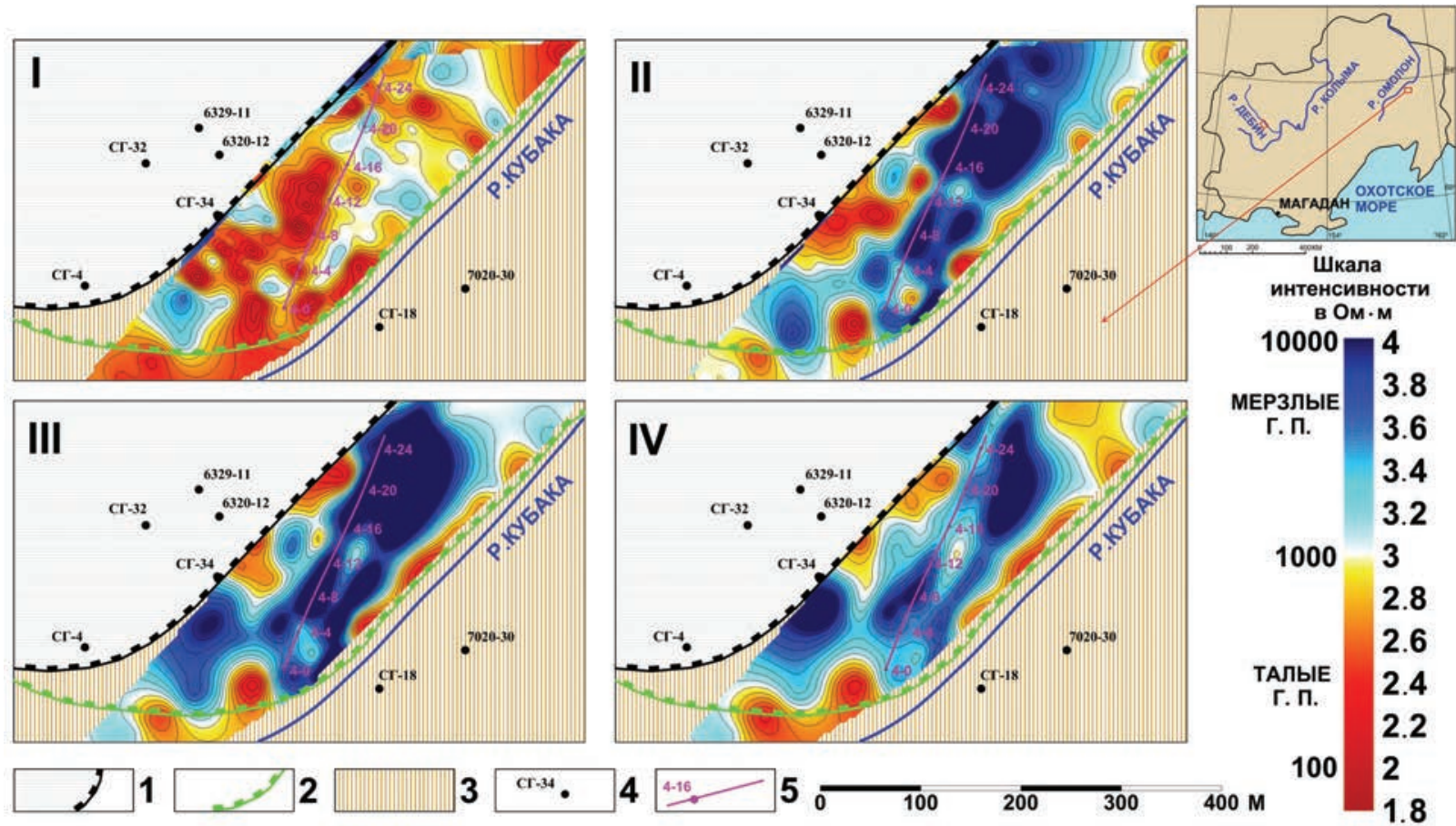

Рис. 4. Планы изолиний параметра удельного сопротивления по результатам работ методом ВЭЗ. Срезы на глубине 10 м (I), 20 м (II), 30 м (III) и 50 м (IV): 1 - территория действующего карьера; 2 - участок проектируемой подземной разработки; 3 - четвертичные рыхлые отложения (ненарушенный поверхностный слой); 4 скважины, их номера; 5 - профиль геолого-геофизического разреза

Fig. 4. Plans of the resistivity parameter isolines based on the results of the VES method works. Slices at depths of $10 \mathrm{~m}$ (I), $20 \mathrm{~m}$ (II), $30 \mathrm{~m}$ (III) and $50 \mathrm{~m}$ (IV): 1 - active quarry area; $\mathbf{2}$ - site of the designed underground operation; 3 - Quaternary loose deposits (undisturbed surface layer); 4 - wells, their numbers; 5 - profile of the geological and geophysical section 


\section{Разрез по данным георадарного профилирования}

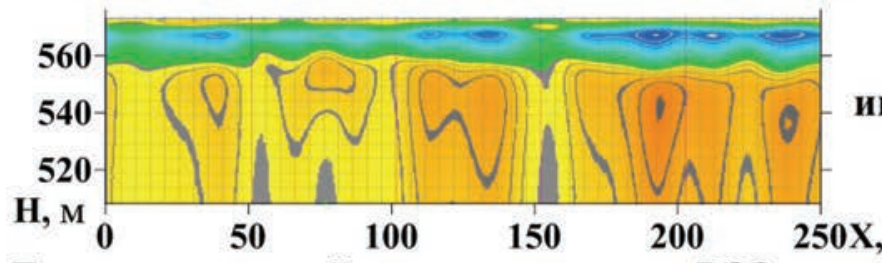

Геоэлектрический разрез по данным ВЭ3
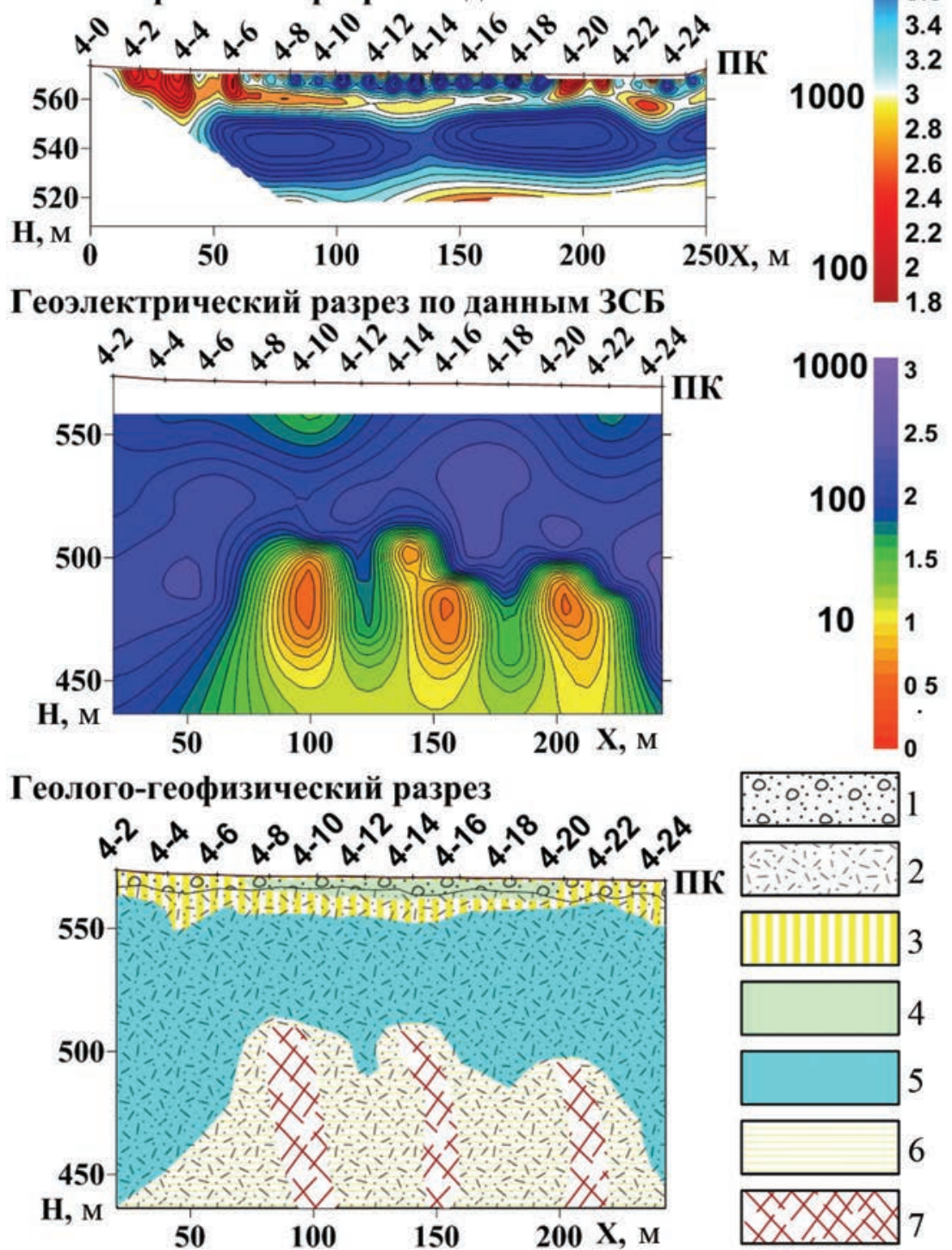

Puc. 5. Геоэлектрические разрезы и их комплексная интерпретация: 1 - рыхлые четвертичные отложения; 2 - вулканогенно-осадочные образования: игнимбриты, туфоалевролиты, туфопесчаники; 3 - талые и обводненные породы водоносного таликового горизонта современных аллювиальных отложений, водоносная таликовая зона трещиноватости раннекаменноугольно-средне-позднедевонских пород (B3Т $\left.\mathrm{C}_{1}-\mathrm{D}_{2-3}\right) ; 4$ - водоупорный криогенный комплекс четвертичных отложений; 5 - водоупорный криогенный массив раннекаменноугольносредне-позднедевонских пород; 6 - талые породы слабоводоносной субкриогенной зоны трещиноватости раннекаменноугольно-средне-позднедевонских пород (СВЗТ $\left.\mathrm{C}_{1}-\mathrm{D}_{2-3}\right) ; 7$ - зоны повышенной трещиноватости и обводненности горных пород

Fig. 5. Geoelectric sections and their complex interpretation: 1 - unconsolidated Quaternary deposits; 2 - volcanicsedimentary formation: ignimbrite, tuffaceous siltstone tuff sandstones; 3 - thawed and water-bearing rocks of the talik aquifer of the modern alluvial deposits, aquifer fracture zone of the Early Carboniferous to Middle-Late Devonian rocks; 4 - waterproof cryogenic complex of Quaternary deposits; 5 - water-resistant cryogenic massif of the Early Carboniferous to Middle-Late Devonian rocks; 6 - thawed rocks of the weakly water-bearing subtrigonal fracture zone of the Early Carboniferous to Middle-Late Devonian rocks; 7 - zones of increased rock fracturing and waterlogging 
Зона интенсивной трещиноватости по данным каротажных работ развита от 20 до 50 м, до этой же глубины отмечаются притоки воды в скважины;

6. Слабоводоносная субкриогенная зона трещиноватости раннекаменноугольно-среднепозднедевонских пород $\left(\mathrm{C}_{1}-\mathrm{D}_{2-3}\right)$ развита повсеместно под толщей ММП. Водовмещающими породами являются те же литологические разности, что и в описанной выше таликовой зоне. Воды напорные и вскрываются на глубине 90130 м, по условиям залегания относятся к подмерзлотным.

Кроме наличия ММП и вышеотмеченных водоносных объектов, на гидрогеологические условия месторождения (прежде всего на интенсивность инфильтрационного питания) оказывают влияние глубина и продолжительность сезонного промерзания на площади развития таликов и протаивания на площади распространения ММП. Мощность сезонно-мерзлых пород в Цокольной зоне составляет 3.0-3.5 м. Глубина протаивания, по данным разведочных работ 19871991 гг., изменяется от 0.3 до 3.0 м и зависит от состава отложений, экспозиции склонов, наличия растительного покрова.

Основными задачами геофизических исследований являлись: изучение мерзлотно-гидрогеологических условий месторождения на участке подземной разработки месторождения; выделение в плане и разрезе областей развития ММП; определение местоположения водоносных таликовых зон.

Результаты выполненных геофизических работ (планы изолиний параметра удельного электрического сопротивления УЭС на глубине 10, 20, 30 и 50 м, геоэлектрические разрезы) представлены на рис. $4,5,6$.

В разрезе на изученную глубину выделяются геоэлектрические неоднородности, соответствующие нижеприведенным гидрогеологическим подразделениям.

Для верхнего слоя, представленного рыхлыми четвертичными отложениями (щебень, галечники, валуны, песок, супесь) и коренными достаточно трещиноватыми осадочными породами (раннекаменноугольные углисто-глинистые сланцы, гравелиты, песчаники), характерны пониженные значения удельного электрического сопротивления и экстремумы отраженного электромагнитного сигнала. В гидрогеологическом отношении данный слой соответствует сезонно-водоносному горизонту четвертичных отложений, водоносному таликовому горизонту современных аллювиальных отложений, а также водоносной таликовой зоне трещиноватости раннекаменноугольносредне-позднедевонских пород $\left(\mathrm{C}_{1}-\mathrm{D}_{2-3}\right)$. Общая мощность слоя 15-20 м.

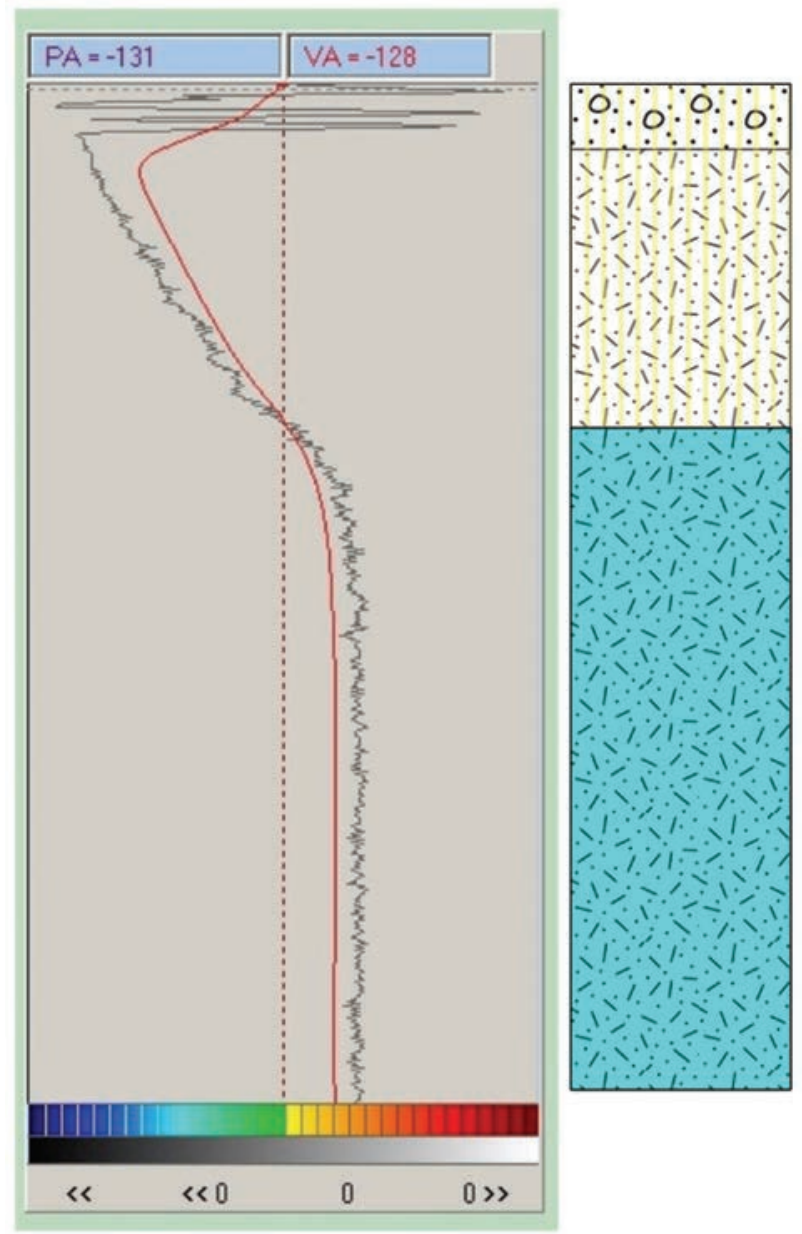

Рис. 6. Пример радарограммы и ее интерпретация. Условные обозначения приведены на рис. 5

Fig. 6. Exemplary radarogram and its interpretation. For symbols, see Fig. 5

В пределах слоя выделено большое количество локальных участков мерзлых рыхлых пород (аномалий повышенного сопротивления), которые в совокупности можно рассматривать как элементы водоупорного криогенного комплекса четвертичных отложений.

Между водоносным таликовым горизонтом современных аллювиальных отложений (в совокупности с сезонно-водоносным горизонтом) и элементами водоносной таликовой зоны трещиноватости раннекаменноугольно-среднепозднедевонских пород водоупора не устанавливается. Оба гидрогеологических подразделения в данном случае представляют собой единую водоносную систему с различной степенью обводненности.

Второй слой характеризуется высокими значениями удельного электрического сопротивления и минимальными значениями отраженного электромагнитного сигнала. Он соответствует толще многолетнемерзлых пород. В разрезе они располагаются в диапазоне глу- 
бин от 10-20 до 60-120 м. Согласно представленной выше гидрогеологической стратификации это водоупорный криогенный массив раннекаменноугольно-средне-позднедевонских пород.

Третий слой с пониженными значениями удельного электрического сопротивления отвечает слабоводоносной субкриогенной зоне трещиноватости с талыми породами раннекаменноугольно-средне-позднедевонских пород $\left(\mathrm{C}_{1}-\mathrm{D}_{2-3}\right)$. Третий и частично второй слой пересекается значительным количеством субвертикальных зон повышенной электрической проводимости, которые фиксируют положение разноранговых зон трещиноватости и высокой обводненности.

На разрезе (см. рис. 5) видно, что до глубины 40-60 м наблюдается повсеместное развитие ММП, что создает благоприятные условия для отработки месторождения. Однако, начиная с 60-80 м в области развития слабоводоносной субкриогенной зоны трещиноватости, осложненной зонами повышенной обводненности, необходимо предусмотреть систему водопонижающих скважин для безопасной разработки месторождения.

Полученные результаты позволяют оценить мерзлотно-гидрогеологические условия Цокольной рудной зоны и выделить три гидрогеологических подразделения: водоносный таликовый горизонт современных аллювиальных отложений (в совокупности с сезонноводоносным горизонтом) и водоносную таликовую зону трещиноватости раннекаменноугольно-средне-позднедевонских пород $\left(\mathrm{C}_{1}-\mathrm{D}_{2-3}\right)$, водоупорный криогенный массив раннекаменноугольно-среднепозднедевонских пород, слабоводоносную субкриогенную зону трещиноватости раннекаменноугольно-среднепозднедевонских пород $\left(\mathrm{C}_{1}-\mathrm{D}_{2-3}\right)$. Установленные зоны повышенной трещиноватости являются наиболее водообильными частями изученного горного массива. Выявленные особенности гидрогеологического строения могут быть использованы при построении фильтрационной модели месторождения.

\section{ЗАКЛЮЧЕНИЕ}

Представленные результаты геофизических исследований продемонстрировали высокую эффективность примененного комплек- са электроразведочных методов для целей выделения талых пород в массиве многолетнемерзлых. Данные методы исследований могут быть рекомендованы для изучения криогенного состояния грунтов, а также инженерногеокриологических процессов. При дражной отработке россыпных месторождений они, несомненно, будут способствовать выделению перспективных промышленных блоков, а для условий подземной разработки золоторудных месторождений в коренных породах - обоснованию участков размещения водопонижающих скважин для обеспечения безопасных условий работы в подземных условиях.

\section{ЛИТЕРАТУРА}

Зыков Ю. Д. Геофизические методы исследования криолитозоны : учебник. Москва : Изд-во МГУ, 2007. $272 \mathrm{c}$.

Кормильцев В. В. Переходные процессы при вызванной поляризации. Москва : Наука, 1980. 111 с.

Мельников В. П., Сквориов А. Г., Малкова Г. В., Дроздов Д. С., Пономарева О. Е., Садуртдинов М. Р., Царев А. М., Дубровин В. А. Результаты изучения геокриологических условий арктических территорий с помощью геофизических методов // Геология и геофизика. 2010. Т. 51, № 1. С. 171-180.

Нерадовский Л. Г. Опыт изучения влияния температуры на удельное электрическое сопротивление мерзлых пород // Геофизика. 2013. № 1. С. 67-70.

Оленченко В. В. Изучение информативности метода ранней стадии вызванной поляризации (РСВП) при решении задач геокриологии : дис. ... канд. геол.минер. наук. Томск, 2002. 211 с.

Хасанов И. М., Алевская Н. Л., Кошурников А. В. Эффективность геофизических методов при изучении криолитозоны в процессе дражной отработки россыпных месторождений // Материалы четвертой конференции геокриологов России, МГУ, 7-9 июня 2011 г. Москва : Университетская книга, 2011а. Т. 1. С. 253257.

Хасанов И. М., Шарафутдинов В. М., Кошурников $A$. В. Оценка влияния криолитозоны при геофизических исследованиях золоторудных месторождений на поисковой стадии, расположенных во вмещающей среде, состоящей из тонкодисперсных осадочных пород // Там же. Москва : Университетская книга, 2011б. T. 1. C. 257-262.

Якупов В. С. Геофизика криолитозоны. Якутск : Изд-во Якутского госуниверситета, 2008. 342 с.

Поступила в редакиию 13.01.2021 2.

Поступила после доработки 02.02.20212. 


\title{
USING GEOPHYSICAL METHODS FOR STUDYING THE CRYOGENIC STATE OF ROCKS AT GOLD DEPOSITS DEVELOPED IN MAGADAN OBLAST
}

\author{
I. M. Khasanov ${ }^{1,3}$, V. N. Volkov \\ ${ }^{I}$ North-East Interdisciplinary Scientific Research Institute n. a. N. A. Shilo, FEB RAS, Magadan \\ ${ }^{2}$ Southern Federal University, Rostov-on-Don \\ ${ }^{3}$ North-Eastern State University, Magadan
}

The authors consider the problem of applicability and sensitivity of methods of ground geophysics for study-ing the state of rock massifs in the permafrost zone. Using the example of gold deposits in Magadan Oblast, they study and analize peculiarities of changes in the values of electrical resistivity and induced polarization of soils, depending on their cryogenic state. Sufficiently high efficiency of geophysical methods in distinguishing thawed, seasonally thawed, locally frozen, and permafrost rocks is substantiated. The research results are recommended for optimizing field development processes in various engineering and geological settings.

Keywords: permafrost, thawed zones, geophysical methods, electrotomography, electrical resistivity, induced polarization.

\section{REFERENCES}

Khasanov, I. M., Alevskaya, N. L., Koshurnikov, A. V., 2011. The Effectiveness of Geophysical Methods in the Study of Permafrost in the Process of Dredging of Placer Deposits, Materials of the Fourth Conference of Geocryologists of Russia, Lomonosov Moscow State University, June 7-9, 2011. Moscow, Universitetskaya Kniga. 1, 253-257 [In Russian].

Khasanov, I. M., Sharafutdinov, V. M., Koshurnikov, A. V., 2011. Assessment of the Permafrost Influence in Geophysical Studies of the Prospecting-Stage Gold Deposits, Located in the Host Environment, Consisting of Fine Sedimentary Rocks, Materials of the Fourth Conference of Russia's Geocryologists, Lomonosov Moscow State University, June 7-9, 2011. Moscow, Universitetskaya Kniga. 1, 257-262 [In Russian].

Kormiltsev, V. V., 1980. Transient Processes in Induced Polarization. Moscow, Nauka [In Russian].

Melnikov, V. P., Skvortsov, A. G., Malkova, G. V., Drozdov, D. S., Ponomareva, O. E., Sadurtdinov, M. R.,
Tsarev, A. M., Dubrovin, V. A., 2010. Results of Studying the Geocryological Conditions of the Arctic Territories Using Geophysical Methods, Russian Geology and Geophysics. 51, 1, 171-180 [In Russian].

Neradovsky, L. G., 2013. Experience in Studying the Effect of Temperature on the Electrical Resistivity of Frozen Rocks, Geophysics. 1, 67-70 [In Russian].

Olenchenko, V. V., 2002. Sensitivity Study of the Informativeness of the Method of the Early Stage of Induced Polarization (ESIP) in Solving Problems of Geocryology, Dis. ... Candidata Geol.-Mineral. Nauk, Tomsk [In Russian].

Yakupov, B. S., 2008. Permafrost Geophysics. Yakutsk, Yakutsk State University Publishing House [In Russian].

Zykov, Yu. D., 2007. Geophysical Methods for the Study of Permafrost, Textbook. Lomonosov Moscow, Publishing House of Moscow State University [In Russian]. 